\title{
INNOVATIVE APPROACH TO SUSTAINABLE MATERIAL SOURCING AND ITS IMPACT ON BUILDING PERFORMANCE
}

\author{
JAIDEEP SINGH RAJPUROHIT, BORIS CERANIC \& DEREK LATHAM \\ Department of Architecture and Civil Engineering, University of Derby, UK
}

\begin{abstract}
In this paper, a novel use of building materials and their impact on the building performance and its climatic adaptability is explored, based on a complex case study of a unique low energy sustainable building project. In particular, an innovative use of sycamore and its suitability as a structural and constructional timber has been investigated and reported, given that the current codes of practice deem that is not appropriate for structural applications due to its durability. A research method of in-situ longitudinal study has been adopted, concentrating on the monitoring and assessment of its structural performance and conditions in which it might deteriorate. On the component level, the research reports on the methods and standards of sycamore grading and classification, service classes, resistance to decay, impact of the moisture movement and results of its laboratory and in situ testing. On the system level, the climatic adaptability of the building as a whole has been analysed via dynamic performance simulation and compared to the in situ measurements. This was important in order to develop a holistic building performance monitoring strategy, but in particular, to understand the impact of building microclimate on the sycamore frame and hempcrete components of the external load-bearing wall. So far research has concluded that sycamore can be used as structural and constructional material in building design, but due attention has to be paid to construction detailing and provision of a breathable, low humidity environment with an effective resistance to decay and insect attack. This includes measures that ensure a low equilibrium moisture content conditions, effective ventilation provision and appropriate service class uses. It is important to state however, given the single site locality of sycamore sourcing, that results can only be interpreted in the context of the given case study, i.e. they cannot be extrapolated to broader geographical extents.
\end{abstract}

Keywords: sycamore,; sustainable design, materials, climatic adaptability, building performance.

\section{INTRODUCTION}

Sycamore, scientifically known as Acer Pseudoplanatus, is a hardwood tree native to Central Europe and Western Asia and belongs to deciduous tree family. With broad leaved, invasive and resilient in its growth, it is capable of germination under almost any conditions. As stated by [1], it has a low ecological count (less than 25) and supports a small variety of insect life, birds and little other wildlife. Hence, its planned and regular harvesting could not only create an additional source of sustainable timber supply but also generate space for other species to grow, improving the biodiversity of woodlands.

Today, sycamore can be found in 3,461 (89.7\%) hectads in Britain, more than any native tree species [2], [3]. Widely available and used among conventional applications like interior joinery, furniture, parquetry and musical instrument making [4], it is not deemed suitable in the construction industry as a structural material due to its perishability and susceptibility to rot and decay, hence could be considered a new paradigm.

Therefore, this research poses challenge to the key principles of sustainable design, raising question why materials which are available locally and in abundance, such as sycamore, are not used more readily, particularly when the majority of structural timber supply in the UK is imported currently from other European countries [4]. 
Although the research on physical and mechanical properties of sycamore as a material have been investigated and reported in the literature [5], none has tested it as the structural material in real building conditions nor monitored its structural integrity in varied moisture conditions over the long period of the time (a longitudinal performance monitoring of at least five years in the Hieron's Wood research project is proposed). Thus, the proposed performance monitoring strategy includes regular testing of its moisture content, condition and integrity of the sycamore structural frame, including measuring the temperature and relative humidity of its immediate environment [6].

\section{CASE STUDY: ENERGY PLUS HOUSE, HEIRON'S WOOD}

\subsection{Research methodology}

The reasoning behind selection of a case study based approach in this research was based on the need to examine performance monitoring through the prism of a complex real word project. The strengths behind choosing case study approach as a valid research method are summarised by [7], stating that it is particularly suitable for analysis of all the complexities and uniqueness of a given project from multiple perspectives, and in real life context. It is considered research based, inclusive of different methods and is evidence-led.

The primary purpose is to generate in depth understanding of a specific topic. According to [8], "the holistic design approach is beneficial when the theory pertinent to the case study itself is of a holistic nature or where no logical sub-units can be identified". However, he further asserts the importance of access to the real world data stating that otherwise the case study may be "an overly abstract, with a lack of suitably clear measures or data".

This research examines sycamore as a novel and sustainable structural material alternative, in the context of the building performance of a single case study and in combination with other materials and integrated passive design strategies. It is triangulated via laboratory experimentation, longitudinal in-situ building performance measurements and building performance simulation analysis.

\subsection{Case study}

Located on the edge of Little Eaton in Derbyshire, Heiron's Wood is an experimental 4bedroom house. It is located on a former stone quarry in the vicinity of an existing 1920's house (see Fig. 1(a), (b)). The design intent was to propose a dwelling with a minimal carbon imprint and visual impact on the landscape of the site, considering its historical and physical context and aided by a locally sourced materials to blend building within its surroundings.

The project represents a distinctive opportunity to undertake long term research in monitoring of building performance with respect to: a) energy consumption/embodied carbons/health and wellbeing; b) innovative use of materials and technology; and c) detail design and construction.

To ensure maximum impact of the heat gains from the warm air as it rises, design is based on an "upside down" plan, with sleeping quarters on the lower ground floor and living areas on the upper ground floor (see Fig. 2(a), (b)):

- The lower ground floor consists of an en-suite master bedroom, two-guest room and a study with utility and garden store, with external excess.

- The upper ground floor has an open living/dining/kitchen, larder, WC and an entrance hall.

- The mezzanine level comprises of an open study balcony, looking down to the living and dining area. 


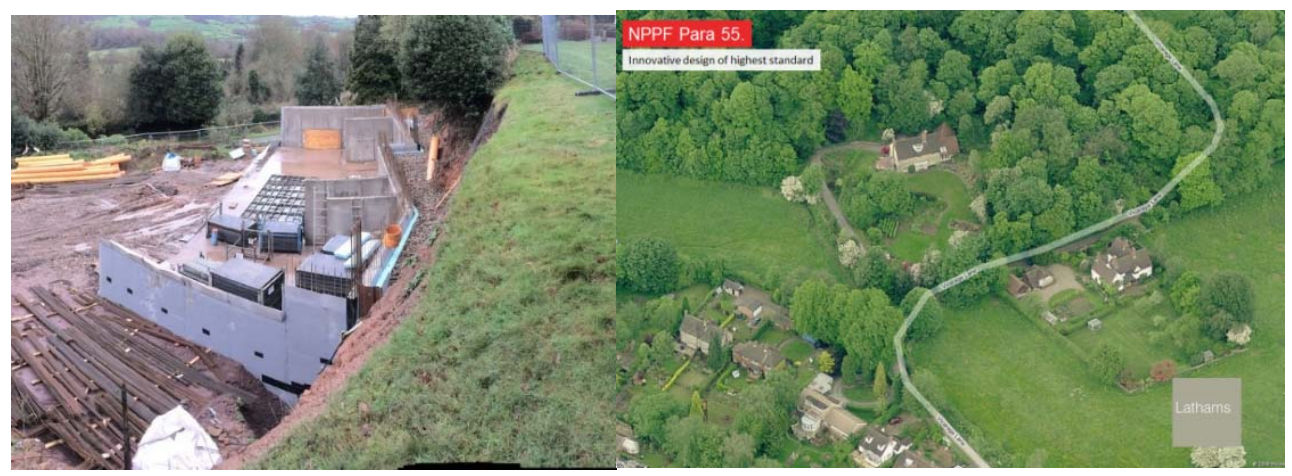

Figure 1: (a) Aerial view of the site location; and (b) Site build progress.
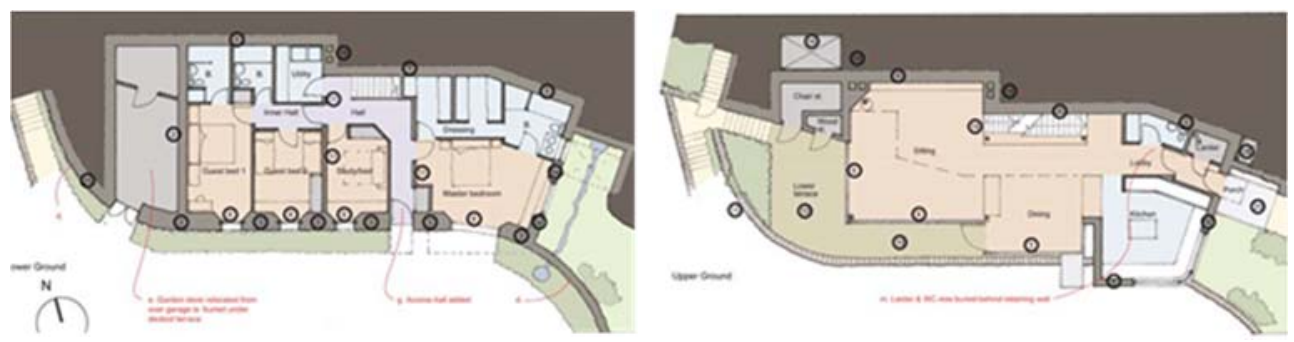

Figure 2: (a) Lower ground floor; and (b) Upper ground floor.

A key principle of an adopted "fabric first" approach was to maximise the performance of the materials and components that make up the building fabric itself, and in doing so create a building that minimises the need for energy consumption in the first place, rather than relying on the mechanical and electrical building services supplies. A number of key design methods were used to achieve this, such as super insulation and airtightness, zoning (see Fig. 2(a), (b)), effective natural ventilation, passive stack and purge ventilation, earth embankment at the northern side, high thermal mass (see Fig. 3(a)), and earth tube as a passive earth to air heat exchange device (see Fig. 3(b)). In addition, the southern orientation of the building maximises its winter solar gains and helps it to capitalise on the PV energy generation (see Fig. 3(b)). Calculations from early energy design simulations show that the building produces more energy through the renewables than it consumes, making it defacto an "energy plus" house.

Figs 4 and 5 below show completed project at the time of client handover.

\section{RESULTS AND DISCUSSION}

\subsection{Structural use of sycamore}

When deployed in the service classes 1 and 2 (see Fig. 6(a), it is important to maintain timber at less than $20 \%$ moisture content as it is likely to perish due to being attacked by wood decaying fungi or sapstain [9]. According to [10] sycamore belongs to class 5 (see Fig. 6(b)), i.e. it is classified as non-durable and perishable in less than five years. 

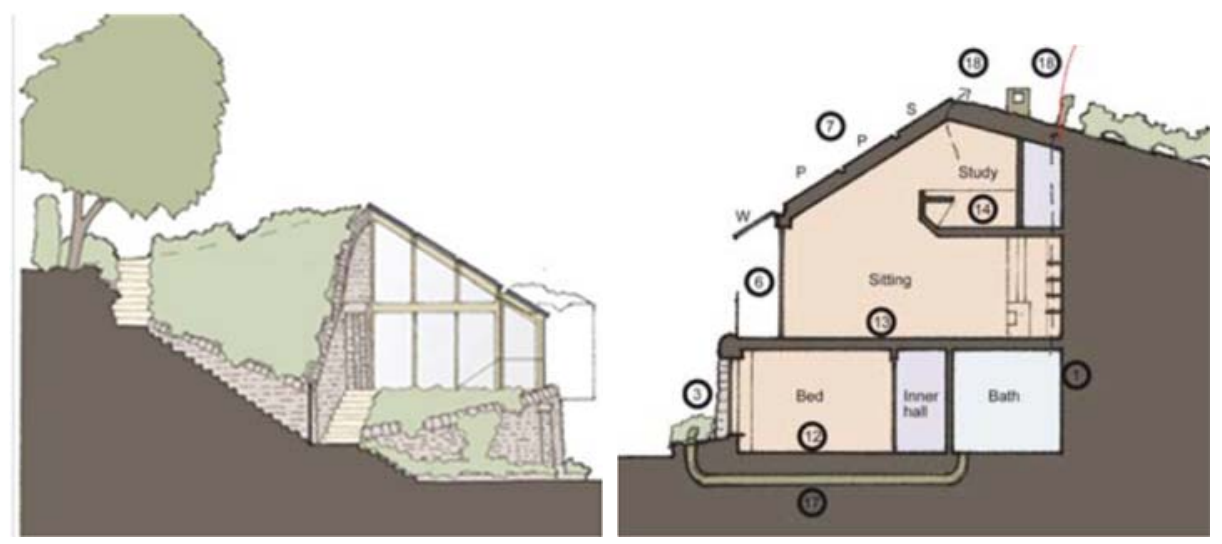

Figure 3: (a) West elevation; and (b) Cross section with southern roof orientation.

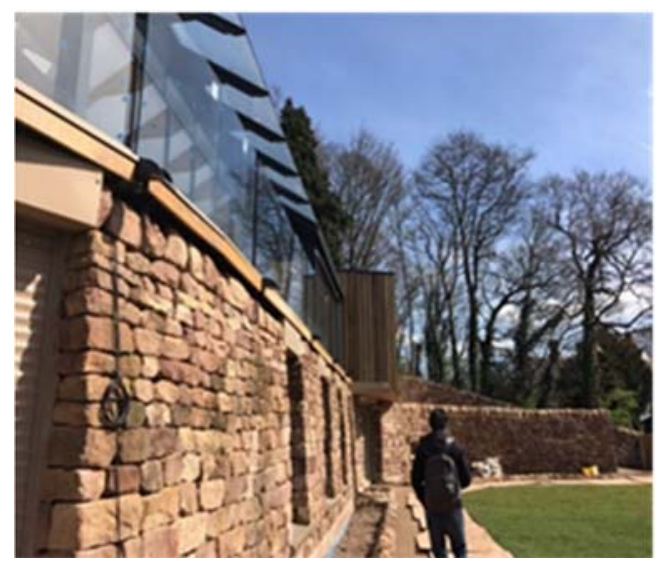

Figure 4: South elevation.

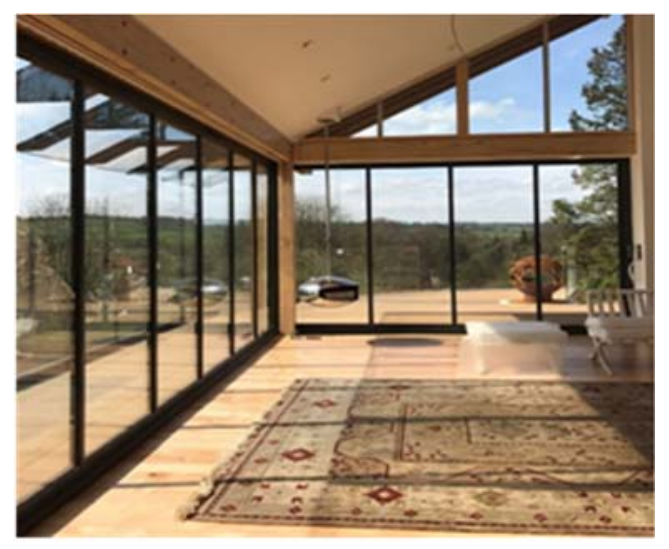

Figure 5: South west view from the living room. 


\begin{tabular}{|l|l|l|}
\hline $\begin{array}{l}\text { Service } \\
\text { Class }\end{array}$ & Examples of use in building & $\begin{array}{l}\text { Typical upper } \\
\text { moisture content } \\
\text { in service }\end{array}$ \\
\hline 1 & $\begin{array}{l}\text { Warm roofs } \\
\text { Intermediate floors } \\
\text { Timber-frame walls, internal and } \\
\text { party walls }\end{array}$ & $12 \%$ \\
\hline 2 & $\begin{array}{l}\text { Cold roofs } \\
\text { Ground floors } \\
\text { Timber-frame walls, external walls } \\
\text { External uses protected from } \\
\text { direct wetting }\end{array}$ & $20 \%$ \\
\hline 3 & External uses, fully exposed & $>20 \%$ \\
\hline
\end{tabular}

\begin{tabular}{|l|l|l|l|}
\hline \multicolumn{2}{|l|}{$\begin{array}{l}\text { BS EN } 350 \\
\text { Durability classes }\end{array}$} & \multicolumn{2}{l|}{ BRE classes } \\
\hline Class & Description & Descriptlon & $\begin{array}{l}\text { Approx Ilfe of } \\
50 \times 50 \mathrm{~mm} \text { stakes } \\
\text { In ground }\end{array}$ \\
\hline 1 & Very durable & Very durable & More than 25 years \\
\hline 2 & Durable & Durable & $15-25$ years \\
\hline 3 & $\begin{array}{l}\text { Moderately } \\
\text { durable }\end{array}$ & $\begin{array}{l}\text { Moderately } \\
\text { durable }\end{array}$ & $10-15$ years \\
\hline 4 & $\begin{array}{l}\text { Slightly } \\
\text { durable }\end{array}$ & Non durable & $5-10$ years \\
\hline 5 & Not durable & Perishable & Less than 5 years \\
\hline
\end{tabular}

Figure 6: (a) Service classes and moisture content; and (b) BS EN 350 Durability classes.

However, this BS EN 350 classification is based on the approximate life of 50x50mm stakes driven into the ground, and as this study argues conducted in conditions much more harsh than is probable within the building envelope.

Thus, the research strategy of using structural sycamore in service classes 1 and 2 is proposed, reinforced with the use of appropriate construction detailing, breathable constructions and quality workmanship as the first line of defence and the use of non-toxic preservatives as the second.

Even though the hardwoods are visually graded in practice [11], it was decided to examine its mechanical structural properties as per [12]; specifically it's bending and compression strength, local modulus of elasticity, as well as recording the density and moisture content of each sample samples. The initial results were similar to the published figures (see Figs 7 and 8), e.g. TRADA reports on sycamore bending strength to be $99 \mathrm{~N} / \mathrm{mm}^{2}$, modulus of elasticity $9400 \mathrm{~N} / \mathrm{mm}^{2}$, density $630 \mathrm{~kg} / \mathrm{m}^{3}$ and compression parallel to grain $48 \mathrm{~N} / \mathrm{mm}^{2}$ [13]. These mechanical properties are similar to other hardwoods, reinforcing the notion that it could be used structurally.

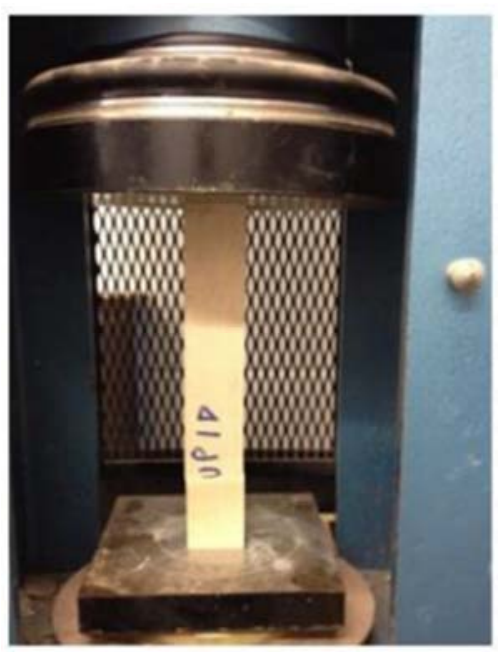

Table IV. Compression Test Results

\begin{tabular}{llll}
\hline $\begin{array}{l}\text { Sample } \\
\begin{array}{l}50 \times 50 \times 300 \\
(\mathrm{~mm})\end{array}\end{array}$ & $\begin{array}{l}\text { Density } \\
\left(\mathrm{kg} / \mathrm{m}^{*}\right)\end{array}$ & $\begin{array}{l}\text { Moisture } \\
\text { Content } \\
(\%)\end{array}$ & $\begin{array}{l}\text { Compressionstrengh ll to } \\
\text { grain (N/mm) }\end{array}$ \\
\hline 1 & 566.8 & $14 \%$ & 33.1 \\
\hline 2 & 572.3 & $14 \%$ & 37.3 \\
\hline 3 & 582.8 & $14 \%$ & 38.6 \\
\hline 4 & 585.9 & $14 \%$ & 41.3 \\
\hline 5 & 591.2 & $14 \%$ & 42.1 \\
\hline 6 & 587.4 & $14 \%$ & 39.9 \\
\hline 7 & 580.3 & $14 \%$ & 38.8 \\
\hline 8 & 577.4 & $14 \%$ & 37.9 \\
\hline 9 & 590.2 & $14 \%$ & 41.3 \\
\hline 10 & 578.6 & $14 \%$ & 38.4 \\
\hline Avg & 581.3 & $14 \%$ & 38.9 \\
\hline SD & 7.8 & 0.00 & 2.6 \\
\hline
\end{tabular}

Figure 7: Compressive strength test. 


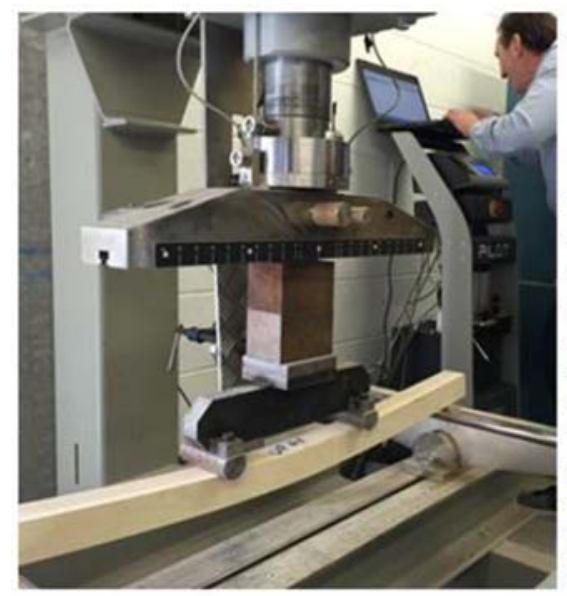

Table V. Bending Strength Test Results

\begin{tabular}{lllll}
\hline $\begin{array}{l}\text { Sample } \\
\begin{array}{l}50 \times 50 \times 1000 \\
(\mathrm{~mm})\end{array}\end{array}$ & $\begin{array}{l}\text { Density } \\
\left(\mathrm{kg} / \mathrm{m}^{*}\right)\end{array}$ & $\begin{array}{l}\text { Moisture } \\
\text { Content } \\
(\%)\end{array}$ & $\begin{array}{l}\text { Local Modulus } \\
\text { of Elasticity } \\
\left(\mathrm{N} / \mathrm{mm}^{2}\right)\end{array}$ & $\begin{array}{l}\text { Bending } \\
\text { Strength } \\
\text { II to grain } \\
\left(\mathrm{N} / \mathrm{mm}^{*}\right)\end{array}$ \\
\hline 1 & 566.8 & $14 \%$ & 9785 & 123.7 \\
\hline 2 & 582.8 & $14 \%$ & 9677 & 96.9 \\
\hline 3 & 571.2 & $14 \%$ & 9406 & 96.7 \\
\hline 4 & 575.6 & $14 \%$ & 9529 & 108.6 \\
\hline 5 & 583.9 & $14 \%$ & 9590 & 91.5 \\
\hline 6 & 575.2 & $14 \%$ & 9350 & 92.6 \\
\hline 7 & 578.3 & $14 \%$ & 9370 & 93.7 \\
\hline 8 & 585.5 & $14 \%$ & 9610 & 97.5 \\
\hline 9 & 579.1 & $14 \%$ & 9512 & 98.6 \\
\hline 10 & 580.2 & $14 \%$ & 9570 & 99.2 \\
\hline Avg & 577.9 & $14 \%$ & 9540 & 99.9 \\
\hline SD & 5.8 & 0 & 137.8 & 9.6
\end{tabular}

Figure 8: Bending strength test.

\subsection{Material performance monitoring strategy}

A long term building performance monitoring strategy (at least five years) of the Hieron's Wood development is proposed (see Fig. 9). It consists of the systematic analysis of the sycamore structural frame on both the component and whole system level. The hempcrete that surrounds sycamore I the external wall is monitored with regards to its moisture content, temperature and relative humidity.

The proposed strategy is supported by the research undertaken on the constructing and testing an experimental built at Hill Holt Wood, Lincoln (see Section 3.3). The wireless monitoring on the site is performed via Ethernet manager and sensors.

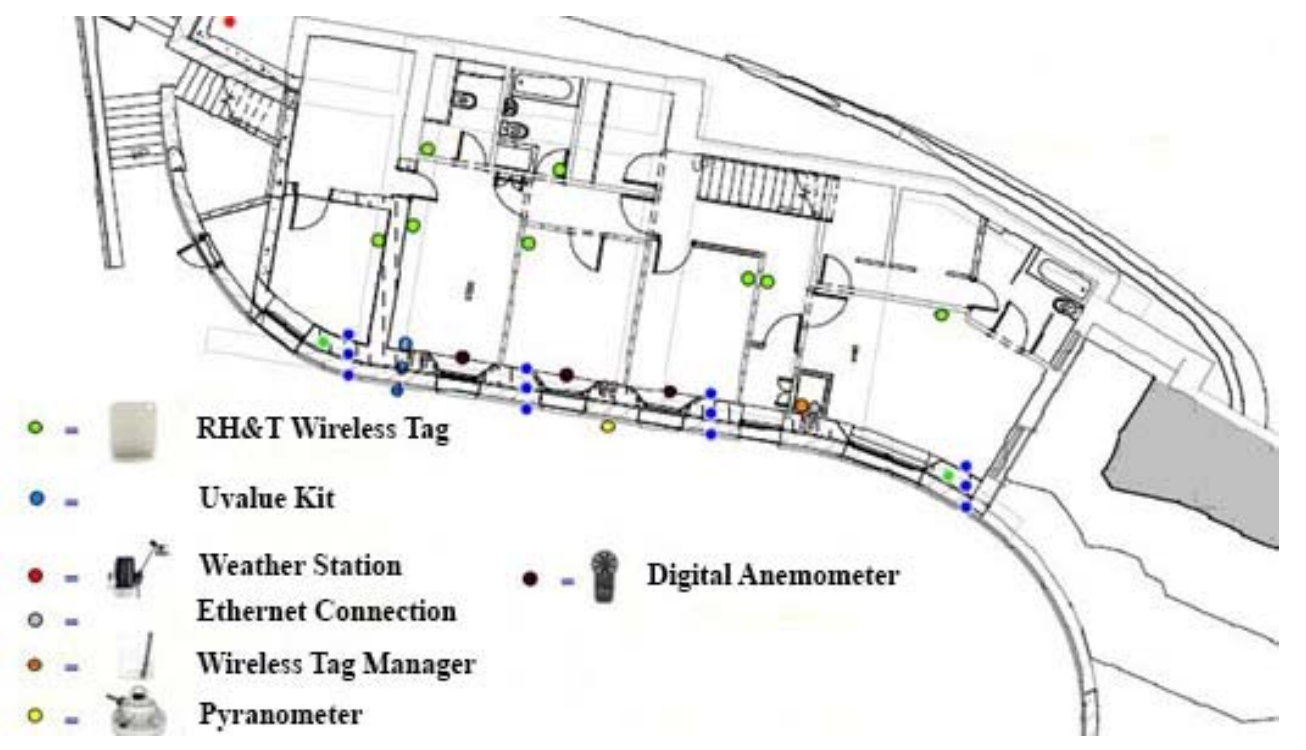

Figure 9: Building performance monitoring strategy: lower ground floor. 


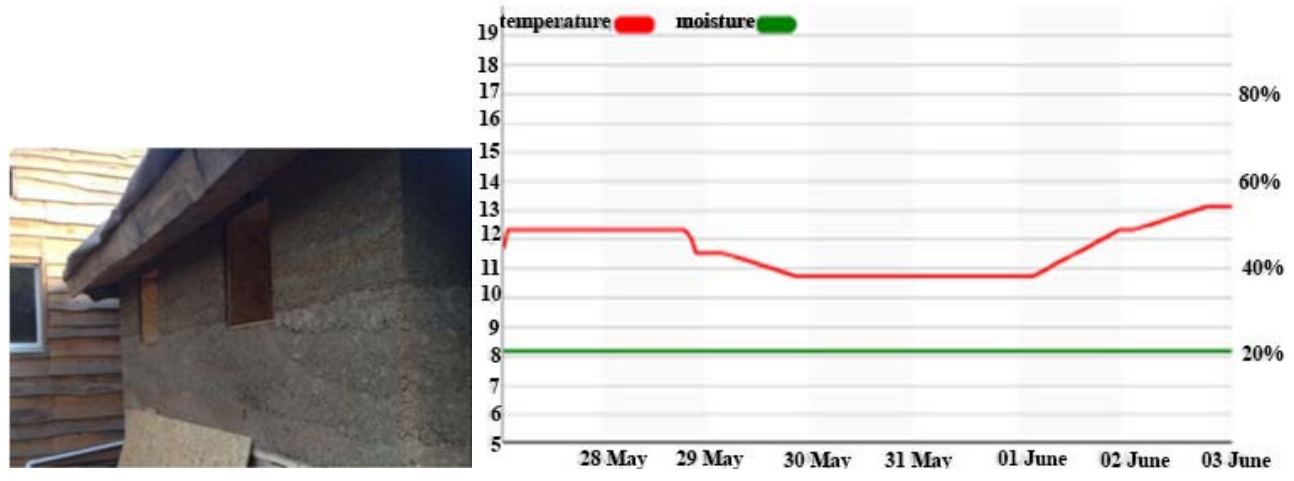

Figure 10: (a) OSB board struck off at the exterior face of the wall; and (b) Temperature and moisture content reading of NW sycamore corner post, 28 May-3 June 2015.

\subsection{Experiment build findings}

The experimental build at Hill Holt Wood, Lincoln was undertaken to evaluate proposed external wall performance behavior, prior to the actual build. It was a small scale timber building with half sycamore and half softwood structural timber frame, and hempcrete infill, forming an external wall with a total thickness of $450 \mathrm{~mm}$. The initial shuttering was with formed with a non-breathable OSB (Orientated Strand Board). The board was struck off from the exterior after the hempcrete has set. It was then rendered with the lime render, keeping the OSB on the interior intact (see Fig. 10(a)).

The temperature and relative humidity sensors installed produced higher moisture readings in the NW corner post, for prolonged periods of time (see Fig. 10(b)). The sycamore was constantly showing moisture content of $20 \%$, even after initial drying of the hemp has taken place. It was observed that the OSB shuttering kept on inside was restricting free moisture movements throughout the wall, resulting in a higher moisture content of the hemp for longer periods, and thus of sycamore too. It was concluded that an envelope has to maintain full breathability and allow for a free and unobstructed moisture movement. Thus the final construction of the external wall for the actual build was fully breathable and composed of, from the outside in, $150 \mathrm{~mm}$ dry stone walling (with a partial bed of lime mortar for stability, but with random air gaps), $10 \mathrm{~mm}$ air gap, $450 \mathrm{~mm}$ hempcrete infill with $150 \times 100 \mathrm{~mm}$ sycamore frame and lime render on the inside [6], providing uninterrupted moisture movement.

\subsection{External wall hygrothermal monitoring}

As the hempcrete surrounding sycamore goes through its intermittent periods of wetting and drying, thus changing its moisture content [6], hygrothermal tests were conducted according to ISO 9869 and ASTM C1046 standards specified in [14], [15], recording heat flux and dynamic changes of $U$-values, to evaluates the building envelope performance and its impact on the sycamore frame. To signify those results, a building envelope performance monitoring of the guest bedroom south facing wall is presented below, covering 3 weeks of typical heating period from 20/02/18-12/03/18 (see Fig. 11). 


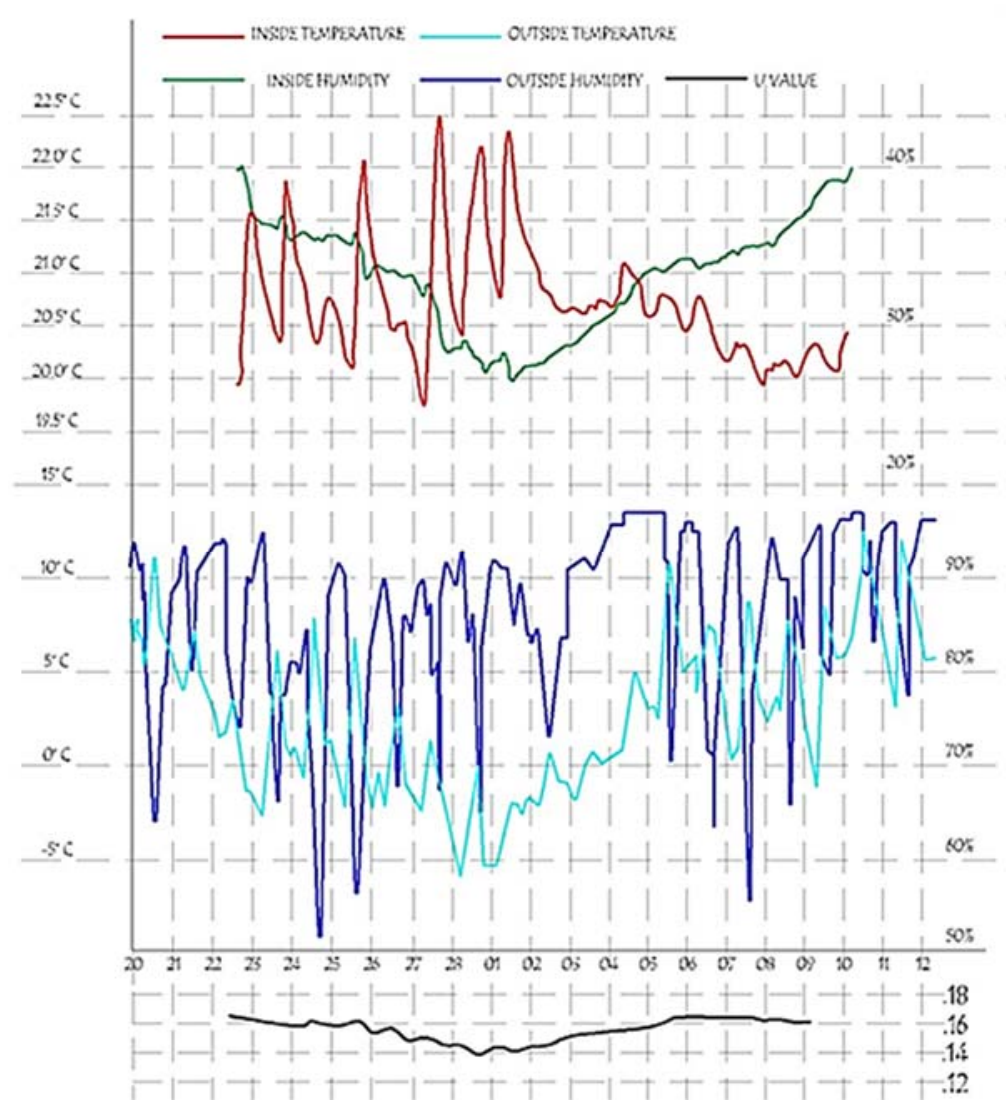

Figure 11: Monitoring results of the guest bedroom south facing wall (20/02/18-11/03/18).

The indoor air temperature was maintained around $20^{\circ} \mathrm{C}$ to $22^{\circ} \mathrm{C}$ with the heating, whilst the outdoor air temperature during this period varied between $-5^{\circ} \mathrm{C}$ and $12^{\circ} \mathrm{C}$. The indoor relative humidity varied between $27 \%$ to $40 \%$, whereas outdoor relative humidity varied between $50 \%$ to $95 \%$. The overall average U-value for the analysed time was around 0.16 $\mathrm{W} / \mathrm{m} 2 \mathrm{~K}$. It was concluded that the changes in the U-value depend on the variation in relative humidity, especially indoor, deteriorating when the hempcrete is in the wetter state and improving when it is in a comparatively dryer state (see Fig. 11).

\subsection{Sycamore moisture content monitoring}

There was a noticable variation in the moisture content of different structural sycamore members depending on their location, for example master bedroom stud (varying between $11 \%$ and $21 \%$ ) and GF plant room stud (varying between $9 \%$ and $15 \%$ ), albeit both being located within the external wall envelope (see Fig. 12 ). The readings of the first floor colums situated in the indoor heated environment on the other hand vary a lot less, between $6 \%$ and $10 \%$. These results indicate the direct correlation between sycamore's service conditions and its moisture content. The timber that sits in the external wall (service class 2) shows higher readings and the range. This is due to the continous wetting and drying of hempcrete which 


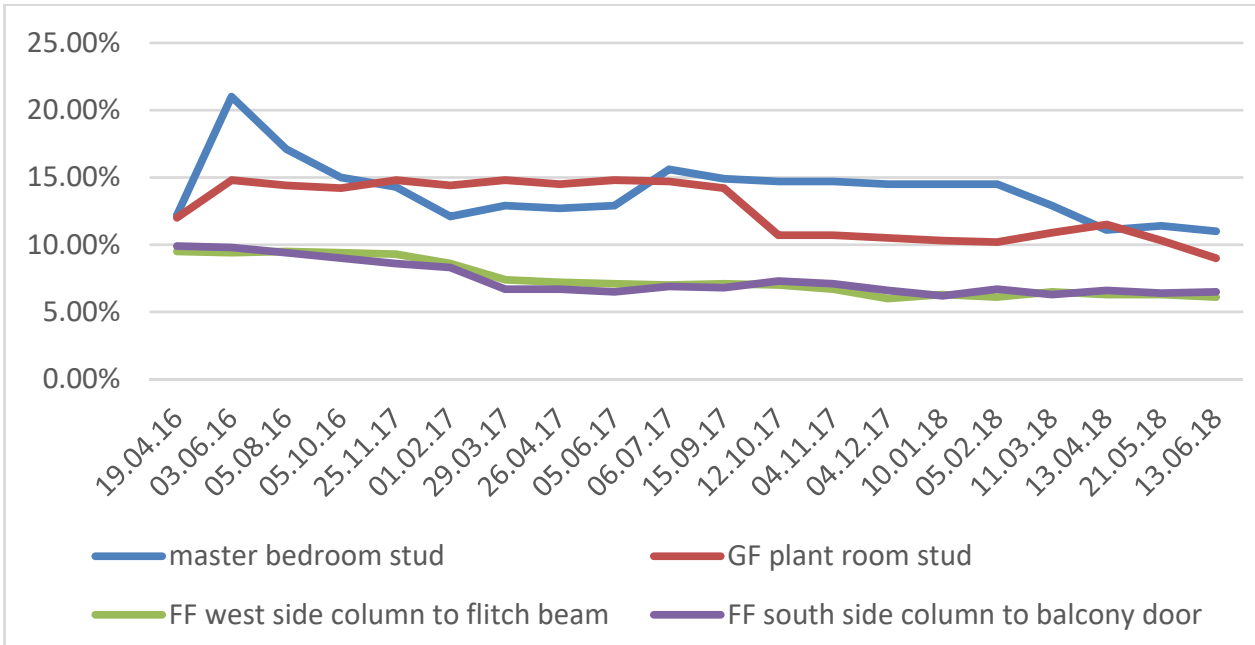

Figure 12: Moisture content readings for sycamore structural members at different locations.
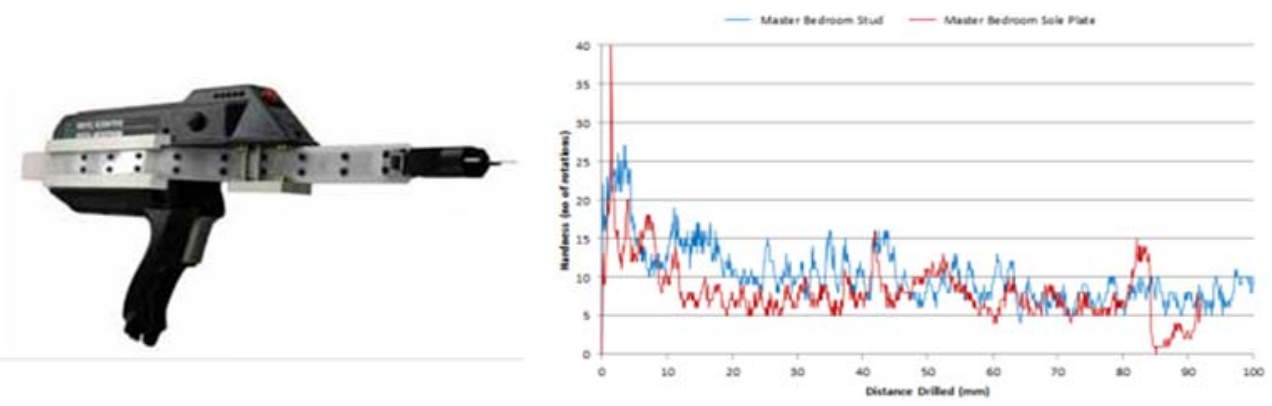

Figure 13: (a) Digital microprobe; and (b) Master bedroom stud and sole plate hardness.

envelopes the sycamore in the external wall. The sycamore on the first floor is situated within the internally controlled environment throughout the year (service class 1) and thus protected from the exposure to changing environmental conditions.

\subsection{Sycamore "hardness" and rate of decay}

To measure sycamore hardness and rate of decay, especially at the "weak" spots such as the junctions between the sole plate and vertical members, a digital microprobe (DmP) was used (see Fig. 13(a)). DmP is used to detect and analyse wood decay by recording the number of rotations required for its needle to make penetration every $0.1 \mathrm{~mm}$. As the fine rapidly rotating probe penetrates the wood, the rate of progress is measured to determine the condition of the wood. Fig. 13 above shows the hardness of the master bedroom stud and sole plate junction. Whilst there are no abrupt decreases in the penetration resistance between the stud and base plate, the latter has some soft wood between 10 and $30 \mathrm{~mm}$ depth, with a potential cavity discovered between 80 and $90 \mathrm{~mm}$. 
4 WHOLE BUILDING SIMULATION AND PERFORMANCE MONITORING

A building energy model produced at the feasibility stage of the project provided an early understanding of energy consumption and costs, water usage, renewables and carbon neutrality potential. 11 scenarios of heating demand were analysed based on calculations performed for air to water aroTHERM 8kW heat pump (CVaillant) [9], results of which are listed in Tables 1 and 2. They show that if heat pump flow temperature is kept at $35^{\circ}$ and energy efficient lighting and appliances are specified throughout the property, then given its constant predicted PV generation capability, the scenarios 5, 6, 7, 8, 9 and 10 become both "energy positive" and "carbon negative".

In the final stage of analysis, a whole building thermal simulation was performed using IES $C<$ VE $>$ software. Final thermal performance calculations were generated, followed by redesigning of the thermal zones according to these results; hence finalising the design for building control approval and commencement of the works on the site. Fig. 14 below shows the actual and notional energy summary, compliant with the Building Regulations Approved Document $\mathrm{L}$ document. The actual building emission rate was estimated at 10.25 $\mathrm{kg} . \mathrm{CO}_{2} / \mathrm{m}^{2}$.yr which is lower than the target emission rate of $16.6 \mathrm{~kg} . \mathrm{CO}_{2} / \mathrm{m}^{2}$.yr. Also, given the carbon emissions "offset" due to the use of PV renewable energy which amounts to -17.7 $\mathrm{kg} . \mathrm{CO}_{2} / \mathrm{m}^{2}$.yr, it makes the building defacto "carbon negative" to the value of -7.52 $\mathrm{kg} . \mathrm{CO}_{2} / \mathrm{m}^{2}$.yr.

Being the residential property, in terms of energy consumption the majority of demand is attributed to the heating (35\%), hot water (43\%) and lighting (19\%), totaling $97 \%$ of the overall consumption, as shown in Tables 3 and 4 (the appliances consumption is excluded). The estimated energy demand is $20.24 \mathrm{kWh} / \mathrm{m}^{2}$, assuming the operational flow temperature of the heat pump $40^{\circ} \mathrm{C}$. Using a lower flow temperature of $35^{\circ} \mathrm{C}$, the energy consumption drops to $18.21 \mathrm{kWh} / \mathrm{m}^{2} / \mathrm{yr}$, and given that $19.23 \mathrm{kWh} / \mathrm{m}^{2} / \mathrm{yr}$ is estimated to be produced from the renewable sources, the net consumption becomes $-1.26 \mathrm{kWh} / \mathrm{m}^{2} / \mathrm{yr}$, making it an "energy positive" proposal.

Table 1: Energy consumption, $\mathrm{PV}$ generation and $\mathrm{CO}_{2}$ emissions estimates (scenarios $1-5)$.

\begin{tabular}{|l|c|c|c|c|c|}
\hline Scenario & 1 & 2 & 3 & 4 & 5 \\
\hline Heating demand $(\mathrm{kWh} / \mathrm{yr})$ & 13389.0 & 13389.0 & 12103.0 & 12103.0 & 11778.0 \\
\hline Solar gains $(\mathrm{kWh} / \mathrm{yr})$ & 0.0 & & & & \\
\hline Internal gains $(\mathrm{kWh} / \mathrm{yr})$ & 0.0 & 500.0 & 500.0 & 500.0 & 1500.0 \\
\hline Flow Temperature ${ }^{\circ} \mathrm{C}$ & 40.0 & 40.0 & 35.0 & 35.0 & 35.0 \\
\hline $\begin{array}{l}\text { Electricity for Heating } \\
\text { (kWh/yr) }\end{array}$ & 3648.2 & 3512.0 & 2967.5 & 2967.5 & 2628.6 \\
\hline DHW demand $(\mathrm{kWh} / \mathrm{yr})$ & 2585.0 & 2585.0 & 2010.0 & 2010.0 & 2010.0 \\
\hline $\begin{array}{l}\text { Electricity for DHW } \\
(\mathrm{kWh} / \mathrm{yr})\end{array}$ & 982.9 & 982.9 & 764.3 & 764.3 & 764.3 \\
\hline $\begin{array}{l}\text { Electricity appliances } \\
(\mathrm{kWh} / \mathrm{yr})\end{array}$ & 3300.0 & 3050.0 & 2800.0 & 2550.0 & 2300.0 \\
\hline $\begin{array}{l}\mathrm{PV} \mathrm{Power} \mathrm{generation} \\
(\mathrm{kWh} / \mathrm{yr})\end{array}$ & 6092.7 & 6092.7 & 6092.7 & 6092.7 & 6092.7 \\
\hline Overall $(\mathrm{kWh} / \mathrm{yr})$ & 1838.4 & 1452.1 & 439.0 & 189.0 & -399.8 \\
\hline $\mathrm{CO}_{2}$ emissions $(\mathrm{kg} / \mathrm{yr})$ & 964.4 & 761.8 & 230.3 & 99.2 & -209.8 \\
\hline
\end{tabular}


Table 2: Energy consumption, $\mathrm{PV}$ generation and $\mathrm{CO}_{2}$ emissions estimates (scenarios 6-10).

\begin{tabular}{|l|c|c|c|c|c|}
\hline Scenario & 6 & 7 & 8 & 9 & 10 \\
\hline Heating demand $(\mathrm{kWh} / \mathrm{yr})$ & 11788.0 & 9266.0 & 9266.0 & 8451.0 & 8451.0 \\
\hline Solar gains $(\mathrm{kWh} / \mathrm{yr})$ & & & & & \\
\hline Internal gains $(\mathrm{kWh} / \mathrm{yr})$ & 1500.0 & 1500.0 & 3000.0 & 3000.0 & 3000.0 \\
\hline Flow Temperature ${ }^{\circ} \mathrm{C}$ & 35.0 & 35.0 & 35.0 & 35.0 & 35.0 \\
\hline Electricity for Heating $(\mathrm{kWh} / \mathrm{yr})$ & 2623.6 & 1986.2 & 1602.6 & 1394.1 & 1994.0 \\
\hline DHW demand $(\mathrm{kWh} / \mathrm{yr})$ & 2010.0 & 2010.0 & 2010.0 & 1800.0 & 1800.0 \\
\hline Electricity for DHW $(\mathrm{kWh} / \mathrm{yr})$ & 764.3 & 764.3 & 764.3 & 684.4 & 684.4 \\
\hline Electricity appliances $(\mathrm{kWh} / \mathrm{yr})$ & 2050.0 & 1800.0 & 1700.0 & 1600.0 & 1500.0 \\
\hline PV Power generation $(\mathrm{kWh} / \mathrm{yr})$ & 6092.7 & 6092.7 & 6092.7 & 6092.7 & 6092.7 \\
\hline Overall $(\mathrm{kWh} / \mathrm{yr})_{\mathrm{CO}_{2} \text { emissions }(\mathrm{kg} / \mathrm{yr})}^{-649.8}$ & -1542.3 & -2025.9 & -2414.2 & 2514.2 \\
\hline
\end{tabular}

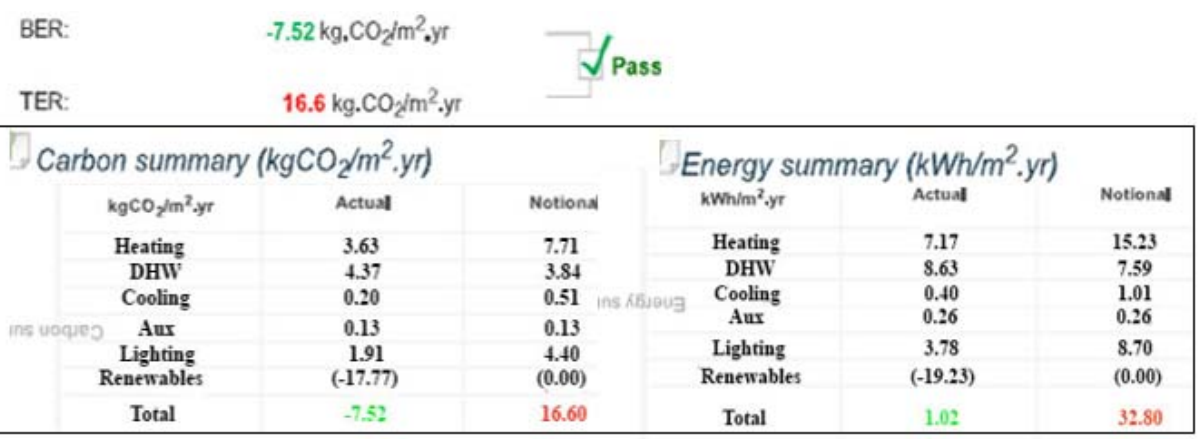

Figure 14: Part L energy summary report.

Table 3: Estimated energy consumption (conditioned area: $347 \mathrm{~m}^{2}$ ).

\begin{tabular}{|c|c|c|c|c|c|c|c|}
\hline $\mathrm{kWh} / \mathrm{m}^{2} \mathrm{yr}$ & Heat & Cool & Aux & Lights & DHW & Renewables & Equipments \\
\hline Jan & 1.38 & 0.00 & 0.02 & 0.39 & 0.73 & -0.37 & 0.70 \\
\hline Feb & 1.04 & 0.00 & 0.02 & 0.33 & 0.65 & -0.59 & 0.63 \\
\hline Mar & 0.91 & 0.00 & 0.02 & 0.33 & 0.73 & -1.22 & 0.70 \\
\hline Apr & 0.76 & 0.00 & 0.02 & 0.28 & 0.73 & -1.86 & 0.68 \\
\hline May & .027 & 0.02 & 0.02 & 0.26 & 0.74 & -2.96 & 0.70 \\
\hline June & 0.05 & 0.06 & 0.02 & 0.24 & 0.71 & -3.35 & 0.68 \\
\hline July & 0.01 & 0.19 & 0.02 & 0.25 & 0.73 & -3.40 & 0.70 \\
\hline Aug & 0.01 & 0.11 & 0.02 & 0.27 & 0.73 & -2.50 & 0.70 \\
\hline Sep & 0.09 & 0.01 & 0.02 & 0.30 & 0.72 & -1.47 & 0.68 \\
\hline Oct & 0.46 & 0.00 & 0.02 & 0.37 & 0.71 & -0.76 & 0.70 \\
\hline Nov & 1.02 & 0.00 & 0.02 & 0.36 & 0.69 & -0.43 & 0.67 \\
\hline Dec & 1.19 & 0.00 & 0.02 & 0.39 & 0.77 & -0.31 & 0.70 \\
\hline Total & $\mathbf{7 . 1 7}$ & $\mathbf{0 . 4 0}$ & $\mathbf{0 . 2 4}$ & $\mathbf{3 . 7 8}$ & $\mathbf{8 . 6 3}$ & -19.23 & $\mathbf{8 . 2 1}$ \\
\hline
\end{tabular}


Table 4: Estimated carbon emissions (conditioned area: $347 \mathrm{~m}^{2}$ ).

\begin{tabular}{|c|c|c|c|c|c|c|c|}
\hline $\mathrm{kWh} / \mathrm{m}^{2} \mathrm{yr}$ & Heat & Cool & Aux & Lights & DHW & Renewables & Equipments \\
\hline Jan & 0.70 & 0.00 & 0.01 & 0.20 & 0.37 & -0.34 & 0.35 \\
\hline Feb & 0.53 & 0.00 & 0.01 & 0.17 & 0.33 & -0.55 & 0.32 \\
\hline Mar & 0.46 & 0.00 & 0.01 & 0.17 & 0.37 & -1.13 & 0.35 \\
\hline Apr & 0.39 & 0.00 & 0.01 & 0.14 & 0.37 & -1.72 & 0.34 \\
\hline May & 0.13 & 0.01 & 0.01 & 0.13 & 0.37 & -2.73 & 0.35 \\
\hline June & 0.02 & 0.03 & 0.01 & 0.12 & 0.36 & -3.09 & 0.34 \\
\hline July & 0.01 & 0.10 & 0.01 & 0.13 & 0.37 & -3.15 & 0.35 \\
\hline Aug & 0.01 & 0.06 & 0.01 & 0.14 & 0.37 & -2.31 & 0.35 \\
\hline Sep & 0.04 & 0.00 & 0.01 & 0.15 & 0.36 & -1.36 & 0.34 \\
\hline Oct & 0.23 & 0.00 & 0.01 & 0.19 & 0.36 & -0.70 & 0.34 \\
\hline Nov & 0.52 & 0.00 & 0.01 & 0.18 & 0.35 & -0.40 & 0.35 \\
\hline Dec & 0.60 & 0.00 & 0.01 & 0.20 & 0.39 & -0.28 & 0.35 \\
\hline Total & $\mathbf{3 . 6 3}$ & $\mathbf{0 . 2 0}$ & $\mathbf{0 . 1 2}$ & $\mathbf{1 . 9 1}$ & $\mathbf{4 . 3 7}$ & -17.77 & $\mathbf{4 . 1 6}$ \\
\hline
\end{tabular}

\section{CONCLUSIONS}

The building used in this research has emerged from a novel design concept, including a distinctive approach to sustainable design and site contextual response, with design and build undertaken by a dedicated team of practitioners and researches. This makes it bespoke, but it does not undermine the importance of this project serving a useful learning precedent as a "one off" innovative design case study. The key conclusions are:

- The compressive and tensile properties of sycamore used are tested according to BS EN standards and proven to be similar to the published figures, although on a small sample of solid wood specimens from within the site boundaries.

- The assignment of visual grades and species in the BS EN 1912:2012 lists a German Standard DIN 4074 Teil 5, which gives grading rules for Acer Pseudoplanatus, ordinarily referred to in the UK as sycamore.

- It is essential to keep sycamore maintained at a moisture content of less than $20 \%$, thus making it significantly less likely to be susceptible to a substantial fungal decay.

- The breathability of walls has to be protected to ensure a free moisture movement and thus prevent sycamore being exposed to prolonged periods of high humidity.

- Evidence of possible decay and issues with the moisture content and hardness of timber can be seen in weak areas on the junctions between the studs and base plate. It is important that their moisture content and rate of decay is measured regularly.

- It is important to dry the sycamore before installing it, in order to keep its moisture content as close as possible to its future in-service condition. $(\mathrm{mc}=14 \%$ for case study).

- There is a significant variation of sycamore moisture content observed over last 2 years, ranging from $6 \%$ to $21 \%$, with the moisture content of sycamore situated within the external wall (SC 2) being significantly higher compared to the sycamore inside (SC 1).

In conclusion, the research demonstrates that sycamore could be used as a structural and constructional material, subject to due care taken to its service class uses, appropriate 
construction detailing for resistance to decay and insect attack, its moisture control and effective ventilation provision.

\section{ACKNOWLEDGMENTS}

Price \& Myers - Structural Engineers, ARUP - Building Services Consultancy, Derek Latham - Architect and Home Owner. Vaillant UK - Building Services Installation.

\section{REFERENCES}

[1] Southwood, T.R.E., The number of species of inspect associated with various trees. Journal of Animal Ecology, 30, pp. 1-8, 1961. DOI: 10.2307/2109.

[2] Stace, C.A. \& Crawley, M.J., Alien Plants, Harper Collins: London, 2015.

[3] BSBI Distribution map, Acer Pseudoplatanus, Botanical Society of Britain and Ireland (BSBI). http://bsbidb.org.uk/maps/?taxonid=2cd4p9h.etk.

[4] Timber Industry Factsheet, Timber in the UK, Publications UK, p. 3, 2013.

[5] Sonderegger, W., Martienssen, A., Nitsche, C., Ozyhar, T., Kaliske, M. \& Niemz, P., Investigations on the physical and mechanical behaviour of sycamore maple (Acer pseudoplatanus L.). European Journal of Wood and Wood Products, 71(1), pp. 91-99, 2013. DOI: $10.1007 / \mathrm{s} 00107-012-0641-8$.

[6] Ceranic, B., Latham, D. \& Dean, A., Sustainable sources and innovative use of building materials: Case study of energy plus house, Hieron's Wood, Derbyshire, UK, International Journal of Energy and Environment, 10, pp. 225-233, 2016.

[7] Simons, H., Case Study Research in Practice, Sage Publications, p. 21, 2009.

[8] Yin, R.K., Case Study Research: Design and Methods (Applied Social Research Methods), Sage Publications, p. 50, 2009.

[9] TRADA. 'Structural Use of Hardwoods', WIS 1-17, TRADA Technology Ltd., 2013.

[10] BS EN 350:1994, Durability of Wood and Wood-Based Products, BSI Copyright, 2013.

[11] BS EN 1912:2012, Structural Timber Strength Classes-Assignment of Visual Grades and Species, BSI Copyright, 2013.

[12] BS EN 408:2010+A1:2012, Timber Structures. Structural Timber and Glued Laminated Timber. Determination of Some Physical and Mechanical Properties, BSI Copyright, 2013.

[13] TRADA, Specifying British-grown Timbers,WIS 2/3-67,TRADA Tech. Ltd., 2013.

[14] ISO 9869-1:2014, Thermal insulation - Building elements - In-situ measurement of thermal resistance and thermal transmittance - Part 1: Heat flow meter method. www.iso.org/standard/59697.html.

[15] ASTM C1046-95, Standard practice for in-situ measurement of heat flux and temperature on building envelope components. www.astm.org/Standards/.

[16] VAILLANTaroTHERM8kW. www.vaillant.co.uk/commercial/products/arotherm$5 \mathrm{kw}-8 \mathrm{kw}-11 \mathrm{kw}$-and-15kw-40000.html. 